\title{
IDENTIFIKASI KLON-KLON KARET BERDASARKAN VARIASI KARAKTERISTIK DAUN
}

\author{
Identification of Rubber Clones Based On Various Leaf Characteristic
}

\author{
Syarifah Aini PASARIBU* dan Irwan SUHENDRY \\ Balai Penelitian Sungei Putih, Pusat Penelitian Karet \\ P.O. Box 1415 Medan 20001 Sumatera Utara \\ *Email: aini_0281@yahoo.com
}

Diterima : 21 Mei 2018 / Disetujui : 30 Mei 2018

\begin{abstract}
Clone indentification is begun from budwood garden, polybag nursery, and immature plant to obtain plants with genetically pure and original. The purpose of this study was to identify rubber clones based on the leaf characteristics by computer and leafgram techniques and also to understand their consistency in different areas. The research were consisted of three series of testing, including 1) to study the effect of clone and growth stage on variability of rubber leaf characteristics for 5 rubber clones (PB 260, IRR 118, IRR 42, BPM 1, PB 330) in nursery, budwood garden, hybridization garden and immature plant, 2) measurement technique by Digital and Leafgram method of 7 clones (IRR 5, IRR 104, IRR 112, PB 217, PB 340, BPM 107, BPM 109), 3) consistency of $P B 260$ leaves characters at three areas (Sungei Putih, Tanah Besih, Parau Sorat, North Sumatra Province). Data was analysed by Nested and Completely Randomized Block Design. The result of the research indicated that leaf characteristics was influenced by the interaction of clone and growth stage. It meant that leaf characteristics of a particular clone were different for different growth stages, except $P / T L, T L / T P$, natural vein, and $A / B$ kite that were not affected by growth environments. Clone identification through "digital" could be replaced with "leafgram". Natural parameters observed were not significantly different by using both techniques. Observations in three different areas showed the same leaf characteristics.
\end{abstract}

Keywords: Clone identification; growth stage; leaf; leafgram; rubber

\section{Abstrak}

Identifikasi klon sejak awal dimulai dari entres, bibit polibeg dan tanaman muda, yang berfungsi untuk mendapatkan tanaman yang murni dan asli secara genetik. Tujuan penelitian ini adalah untuk mengidentifikasi klon berdasarkan karakteristik daun dengan teknik komputer dan leafgram serta mengetahui konsistensinya di beberapa daerah yang berbeda. Penelitian terdiri dari tiga seri pengujian, yaitu: 1) mempelajari pengaruh klon dan stadia pertumbuhan terhadap variabilitas karakteristik daun karet pada 5 klon (PB 260, IRR 118, IRR 42, BPM 1, PB 330) di pembibitan. 2) teknik pengukuran (Digital dan Leafgram) pada 7 klon (IRR 5, IRR 104, IRR 112, PB 217, PB 340, BPM 107, BPM 109), dan 3) konsistensi karakter daun di tiga daerah berbeda (Sungei Putih, Tanah Besi dan Parau Sorat, Provinsi Sumatera Utara) klon PB 260. Data dianalisis dengan rancangan petak tersarang dan acak kelompok. Hasil penelitian menunjukkan bahwa karakteristik daun dipengaruhi oleh interaksi klon dan stadia pertumbuhan. Karakteristik daun suatu klon berbeda diantara stadia pertanaman, kecuali $\mathrm{P} / \mathrm{TL}$, TL/TP, vena alami, dan A/B layang, karena diduga tidak dipengaruhi lingkungan tumbuh. Teknik identifikasi klon secara "digital" dapat digantikan dengan teknik "leafgram". Parameter-parameter alami yang diamati terlihat tidak berbeda nyata diantara kedua teknik tersebut. Pengamatan di tiga daerah yang berbeda terlihat menunjukkan karakteristik daun yang sama .

Kata kunci : Daun; identifikasi klon, karet; leafgram; stadia pertumbuhan 


\section{PENDAHULUAN}

Keseragaman pertumbuhan tergantung kepada murni atau tidaknya klon yang ditanam. Suatu pertanaman yang terdiri dari beberapa klon pada umumnya menghasilkan pertanaman yang tidak seragam. Identifikasi klon diperlukan pada setiap stadia pertanaman karet seperti pembibitan, kebun entres, sampai kepada areal komersial, bahkan sudah harus dimulai sejak pemilihan klon induk dalam persilangan buatan, sehingga turunan yang dihasilkan dapat diketahui secara pasti tetua jantan atau betinanya.

Salah satu bagian tanaman yang dapat dijadikan alat penciri klon adalah daun (Hearn \& David, 2009; Cerutti, et al., 2013; Laga et al., 2014; Zhao et al., 2015) karena daun memiliki bentuk dan ukuran yang spesifik diantara klon serta relatif stabil pada berbagai kondisi lingkungan. Hasil penelitian sebelumnya yang dilakukan Suhendry dan Pasaribu (2009) menunjukkan bahwa daun karet memiliki karakteristik kuantitatif yang spesifik di antara klon, sehingga karakteristik yang terdapat pada daun dapat dipergunakan sebagai penciri dalam mengidentifikasi suatu klon karet. Daun menangkap cahaya untuk fotosintesis, menyerap karbon dioksida, dan mentransformasikan air untuk pendinginan dan sirkulasi. Pengaruh faktor genetik dan kondisi lingkungan merupakan salah satu hal yang memberikan isyarat pada tanaman untuk memperluas area permukaan daun (Volkenburgh, 1999).

Penelitian sebelumnya (Suhendry \& Pasaribu, 2009) menyatakan bahwa variasi dari ukuran dan panjang daun, luas daun, rasio panjang dan lebar daun, proporsi karakter panjang dan lebar daun, sudut daun, dan proporsi sudut daun serta nilainilai konversinya berbeda sangat nyata diantara klon, sehingga dapat dijadikan penciri dalam mengidentifikasi klon karet. Hasil lain juga menunjukkan bahwa pengambilan contoh sangat sensitif terhadap hasil identifikasi. Adanya perbedaan di antara helaian daun menunjukkan bahwa selain abnormalitas yang kontras, perbandingan antar helaian daun yang tidak proporsional dan tidak lazim (meskipun bentuk dan ukurannya normal) juga dapat mempengaruhi hasil identifikasi. Selain itu operator juga menimbulkan perbedaan yang nyata terhadap sebagian besar parameter yang diamati, yang disebabkan perbedaan keterampilan masing-masing operator.

Untuk menyempurnakan hasil penelitian sebelumnya (Suhendry \& Pasaribu, 2009), pemanfaatan teknik komputer dilakukan untuk mengetahui variasi karakteristik kuantitatif daun karet dari beberapa klon pada beberapa stadia pertumbuhan (bibit polibeg, kebun entres, kebun silang, dan tanaman belum menghasilkan) dengan perbaikan teknik pengambilan contoh. Daun yang tidak tumbuh normal bentuk dan ukuran, serta tidak proporsional luasnya antara setiap helaian daun dalam satu tangkai, tidak dipergunakan sebagai contoh. Selanjutnya hasil penelitian tersebut dipergunakan sebagai bahan pertimbangan untuk melakukan pengujian terhadap metode identifikasi menggunakan "leafgram" yang dilakukan secara manual dan dibandingkan dengan metode komputer. Contoh daun yang dipergunakan hanya helaian daun tengah saja dengan pertimbangan bahwa dari pengujian sebelumnya variasi antar helaian tidak nyata, ukuran daun tengah dominan lebih besar dari helaian daun lain.

Adapun tujuan penelitian ini adalah untuk mengidentifikasi karakteristik daun terhadap klon yang berbeda dengan menggunakan metode komputer dan leafgram serta melihat konsitensinya pada beberapa daerah yang berbeda.

\section{BAHAN DAN METODE}

Penelitian dilaksanakan pada MaretDesember 2015 di Kebun Percobaan Balai Penelitian Sungei Putih, melalui tahap kegiatan yaitu :

\section{Kegiatan 1: Pengaruh klon dan stadia pertumbuhan terhadap variabilitas karakteristik daun karet}

Contoh daun masing-masing sebanyak 10 tangkai diambil secara acak dari 5 klon (PB 260, IRR 118, IRR 42, BPM 1, dan PB 330) yang tumbuh pada empat stadia pertumbuhan, yaitu $\mathrm{S} 1=$ bibit polibeg dua payung, $\mathrm{S} 2=$ kebun entres, S3= kebun persilangan, dan $\mathrm{S} 4=$ tanaman belum 
menghasilkan umur tiga tahun. Daun yang abnormal dan memiliki ukuran dan bentuk helaian yang tidak proporsional, tidak dipilih sebagai contoh. Tangkai dan helaian daun contoh diberi nomor urut, kemudian daun ditransfer ke dalam format digital melalui scanner. Dengan memanfaatkan Software Adobe Photoshop, helaian daun dari setiap tangkai dipisahkan menjadi helaian kiri, tengah, dan kanan di dalam satu file yang sama. Posisi daun tersebut disesuaikan dengan letak daun di dalam tangkai pada saat berada di tanaman. Analisis data untuk mengetahui pengaruh klon (K), stadia pertumbuhan (S), tangkai daun di dalam klon $(\mathrm{T} / \mathrm{K})$, helaian di dalam tangkai pada masing-masing klon (H/TK), dan interaksi antara $\mathrm{S} \times \mathrm{K}$ dilakukan melalui analisis keragaman dengan model petak tersarang (Keppel \& Wickens, 1973) sebagai berikut :

$$
Y i j k=u+O i+K j+T k / K j+H l / T k K j+E
$$

Dimana (Remaks): Yijk= Respon yang ditimbulkan pada unit percobaan yang mendapat perlakuan kombinasi operator sebanyak i taraf, klon sebanyak $\mathrm{j}$ taraf dengan ulangan $\mathrm{ke}-\mathrm{k}, \mathrm{O}=$ Operator, $\mathrm{K}=\mathrm{klon}$, $\mathrm{T} / \mathrm{K}=$ tangkai daun di dalam masing-masing klon, $\mathrm{H} / \mathrm{TK}=$ helaian daun di dalam tangkai pada masing-masing klon, dan $\mathrm{E}=$ galat

\section{Kegiatan 2 : Pengujian teknik pengukuran (Digital dan Leafgram) karakteristik daun karet}

Daun contoh dari helaian tengah masing-masing sebanyak 15 tangkai diambil secara acak dari 7 klon (IRR 5, IRR 104, IRR 112, PB 340, PB 217, BPM 107, dan BPM 109) yang tumbuh pada kebun entres. Daun yang abnormal dan memiliki ukuran dan bentuk helaian tidak proporsional, tidak dipilih sebagai contoh. Daun tengah dipisahkan dari tangkai, diberi nomor identitas kemudian daun ditransfer ke dalam format digital melalui scanner. Dengan bantuan Software Adobe Photoshop, contoh daun dicropping dan diukur parameter pencirinya. Daun yang telah dipidai selanjutnya diukur secara manual sesuai dengan identitas yang sama dengan yang terekam di komputer. Pengukuran parameter dengan menggunakan "leafgram" dilakukan oleh operator yang sama. Analisis data untuk mengetahui pengaruh metode $(\mathrm{M})$, klon $(\mathrm{K})$, dan interaksi antara $\mathrm{M} \times \mathrm{K}$ dilakukan melalui analisis keragaman dengan model acak kelompok, dimana sampel tangkai daun menjadi pengulang.

$$
Y i j k=u+T k+M i+K j+M i K j+E
$$

Dimana (Remaks): Yijk: Respon yang ditimbulkan pada unit percobaan yang mendapat perlakuan kombinasi metode pengukuran sebanyak i taraf, klon sebanyak $\mathrm{j}$ taraf dengan ulangan ke- $\mathrm{k}, \mathrm{T}=$ tangkai daun (ulangan), $\mathrm{M}=$ metode pengukuran, $\mathrm{K}=\mathrm{klon}$, $\mathrm{MK}=$ interaksi antara metode dengan klon, dan $\mathrm{E}=$ galat

\section{Kegiatan 3. Konsistensi ukuran daun di kebun entres yang berbeda}

Contoh daun diambil dari tiga tempat yang berbeda yaitu kebun entres Sungei Putih (Kabupaten Deli Serdang), Tanah Besi PT. Socfindo (Kabupaten Serdang Bedagai), dan Desa Parau Sorat (Kabupaten Tapanuli Selatan), Provinsi Sumatera Utara. Klon yang diamati adalah PB 260 dengan contoh daun masing-masing sebanyak 15 daun tengah. Pengukuran daun dilakukan dengan menggunakan leafgram. Perbedaan ketiga lokasi pengambilan sampel daun dapat dilihat pada Tabel 1.

\section{Parameter Penciri}

Pada ketiga kegiatan penelitian tersebut diukur beberapa parameter yang sama. Tiga karakter kuantitatif utama yang dijadikan parameter dalam penelitian ini adalah ukuran panjang, lebar daun maksimum, dan sudut pada beberapa bagian daun. Sedangkan karakter kualitatif lain seperti warna daun, bentuk penampang, gelombang tepi daun, pola urat daun, dan lainnya tidak dipergunakan. Dari ketiga karakter kuantitatif utama tersebut dikembangkan berbagai ukuran dan nilainilai ratio atau indeks sebagai berikut:

\section{Ukuran Panjang}

1. Panjang daun (P) diukur dengan skala sentimeter dari ujung bawah daun (basis) hingga ke ujung atas daun (apeks)

2. Letak titik pusat daun (TP) adalah setengah dari panjang daun

3. Letak titik lipat daun (TL) adalah panjang tulang daun dari titik lipatan pada lebar daun maksimum ke arah apeks 
Tabel 1. Kondisi lingkungan tumbuh di kebun entres tempat pengambilan contoh daun klon PB 260

Table 1. Environmental conditions in budwood garden where sampling of PB 260 leaves.

\begin{tabular}{|c|c|c|}
\hline No. & $\begin{array}{l}\text { Nama daerah } \\
\text { Regional name }\end{array}$ & $\begin{array}{l}\text { Kondisi lingkungan tumbuh } \\
\text { Environmental conditions }\end{array}$ \\
\hline 1. & $\begin{array}{l}\text { Desa Tanah Besih, } \\
\text { Kecamatan Syahbandar, } \\
\text { Kabupaten Serdang Bedagai }\end{array}$ & $\begin{array}{l}\text { Topografi datar sampai bergelombang dengan } \\
\text { ketinggian tempat } 24-26 \mathrm{mdpl} \text {, curah hujan } 1776 \\
\mathrm{~mm} / \text { tahun, suhu } 25-27^{\circ} \mathrm{C} \text { dan kelembaban } 80-90 \%\end{array}$ \\
\hline 2. & $\begin{array}{l}\text { Desa Sungei Putih, } \\
\text { Kecamatan Galang, } \\
\text { Kabupaten Deli Serdang }\end{array}$ & $\begin{array}{l}\text { Areal dataran rendah dengan ketinggian } 54 \mathrm{mdpl} \text {, } \\
\text { curah hujan } 1753 \mathrm{~mm} / \text { tahun, suhu } 26,7^{\circ} \mathrm{C} \text { dan } \\
\text { kelembaban } 84 \%\end{array}$ \\
\hline 3. & $\begin{array}{l}\text { Desa Parau Sorat, } \\
\text { Kecamatan Sipirok, } \\
\text { Kabupaten Tapanuli Selatan }\end{array}$ & $\begin{array}{l}\text { Topografi pegunungan, terdiri dari banyak lembah } \\
\text { dan jurang yang dalam, ketinggian } 700-1700 \mathrm{mdpl} \text {, } \\
\text { curah hujan } 2476 \mathrm{~mm} / \text { tahun, suhu } 22^{\circ} \mathrm{C} \text { dan } \\
\text { kelembaban } 88 \% \text {. }\end{array}$ \\
\hline
\end{tabular}

\section{Ukuran Lebar}

1. Lebar daun (L) diukur dengan skala sentimeter pada lebar daun maksimum

2. Lebar helaian daun sebelah kiri vena (HKr) diukur pada posisi lebar daun maksimum dari batas tepi kiri daun hingga tulang daun tengah

\section{Sudut Daun}

1. Sudut basis alami (B) diukur dengan menggunakan busur pada pada bagian bawah daun mengikuti batas tepi daun dengan titik pusat busur pada pangkal tangkai helaian daun.

2. Sudut apeks alami (A) diukur dengan cara yang sama dengan titik pusat busur pada bagian ujung daun.

3. Sudut vena $(\mathrm{V})$ merupakan besar sudut antara vena terhadap tulang daun yang diukur pada salah satu vena yang berada di sekitar titip lipat daun.

4. Sudut basis layang-layang (BL) merupakan sudut yang terbentuk dari pangkal tangkai helaian daun sampai ke sisi luar daun pada lebar daun maksimum.

5. Sudut apeks layang-layang (AL) merupakan sudut yang terbentuk dari ujung helaian daun sampai ke sisi luar daun pada lebar daun maksimum.

Dari ukuran-ukuran ketiga karakteristik daun tersebut dikembangkan beberapa parameter lain yang terdiri dari :

1. Ratio panjang dan lebar daun $(\mathrm{P} / \mathrm{L})$

2. Ratio panjang daun terhadap titik lipat $(\mathrm{P} / \mathrm{Tl})$
3. Ratio titik lipat terhadap titik pusat (Tl/Tp)

4. Ratio titik lipat terhadap lebar daun (Tl/L)

5. Ratio lebar daun sisi kiri dari vena terhadap lebar daun sisi kanan dari vena pada satu helaian daun yang sama ( $\mathrm{HKr} / \mathrm{HKn})$

6. Ratio lebar helaian daun sisi kiri terhadap titik lipat ( $\mathrm{HKr} / \mathrm{Tl})$

7. Ratio lebar helaian daun sisi kiri terhadap titik pusat $(\mathrm{HKr} / \mathrm{Tp})$

8. Ratio sudut apeks alami terhadap sudut basis alami (A/B)

9. Ratio sudut vena terhadap sudut apeks alami (V/A)

10. Ratio sudut vena terhadap sudut basis alami (V/B)

11. Ratio sudut apeks terhadap sudut basis layang-layang (AL/BL)

\section{HASIL DAN PEMBAHASAN}

\section{Variasi Antar Stadia Pertumbuhan}

Hasil penelitian menunjukkan bahwa seluruh parameter kuantitatif yang diamati berbeda menurut klon dan sejalan dengan penelitian sebelumnya yang dilakukan oleh Suhendry dan Pasaribu (2009). Hasil ini memperkuat dugaan bahwa daun karet memiliki ciri spesifik yang dapat dipergunakan untuk mengidentifikasi antar klon karet (Tabel 2). 
Tabel 2. Kuadrat tengah (KT) analisis keragaman daun karet di antara klon dan stadia pertanaman

Table 2. Mean square analysis of variation rubber leaf between clone and growth stage

\begin{tabular}{|c|c|c|c|c|c|c|c|c|c|c|c|}
\hline \multirow{3}{*}{$\begin{array}{c}\text { Peubah } \\
\text { Characters }\end{array}$} & \multicolumn{11}{|c|}{$\begin{array}{l}\text { Sumber keragaman (Source of square) } \\
\mathrm{db}=\text { derajat bebas (Freedom of degree) }\end{array}$} \\
\hline & \multicolumn{2}{|l|}{$\mathrm{K}$} & \multicolumn{2}{|l|}{$\mathrm{S}$} & \multicolumn{2}{|c|}{$\mathrm{H} / \mathrm{TK}$} & \multicolumn{2}{|c|}{$\mathrm{T} / \mathrm{K}$} & \multicolumn{2}{|c|}{$\mathrm{K} \times \mathrm{S}$} & \multirow{2}{*}{$\frac{\text { Galat }}{(435)}$} \\
\hline & (4) & & (3) & & $(100)$ & & (45) & & (12) & & \\
\hline Ratio P/L & 2,681 & ** & 0,855 & ** & 0,024 & tn & 0,069 & $* *$ & 0,349 & $* *$ & 0,025 \\
\hline $\mathrm{P} / \mathrm{TL}$ & 0,691 & $* *$ & 0,103 & tn & 0,049 & tn & 0,094 & $* *$ & 0,059 & tn & 0,041 \\
\hline TL/TP & 0,069 & $* *$ & 0,012 & tn & 0,006 & tn & 0,012 & $* *$ & 0,009 & tn & 0,005 \\
\hline TL/L & 0,453 & $* *$ & 0,113 & $* *$ & 0,008 & tn & 0,028 & $* *$ & 0,080 & $* *$ & 0,013 \\
\hline $\mathrm{HKr} / \mathrm{TL}$ & 0,101 & ** & 0,024 & $* *$ & 0,005 & th & 0,008 & ** & 0,026 & $* *$ & 0,004 \\
\hline $\mathrm{HKr} / \mathrm{TP}$ & 0,082 & $* *$ & 0,026 & $* *$ & 0,003 & $* *$ & 0,003 & ** & 0,015 & $* *$ & 0,001 \\
\hline Apeks alami & 2975,115 & $* *$ & 194,819 & $\operatorname{tn}$ & 48,333 & tn & 145,967 & $* *$ & 875,844 & $* *$ & 78,899 \\
\hline Basis alami & 4290,797 & $* *$ & 3061,347 & $* *$ & 99,417 & ** & 83,808 & $* *$ & 1057,067 & $* *$ & 49,396 \\
\hline Vena alami & 114,9583 & $* *$ & 18,983 & tn & 7,965 & tn & 22,812 & ** & 17,958 & tn & 11,135 \\
\hline Basis layang & 1034,992 & ** & 390,223 & $* *$ & 25,247 & tn & 34,143 & ** & 189,043 & $* *$ & 20,381 \\
\hline Apeks layang & 971,2402 & $* *$ & 259,473 & $* *$ & 20,659 & tn & 59,809 & $* *$ & 152,154 & $* *$ & 36,782 \\
\hline A/B alami & 0,4704 & $* *$ & 0,502 & $* *$ & 0,028 & * & 0,024 & $\operatorname{tn}$ & 0,109 & $* *$ & 0,021 \\
\hline V/A alami & 0,1977 & $* *$ & 0,0153 & $* *$ & 0,0026 & tn & 0,0069 & $* *$ & 0,0413 & $* *$ & 0,0043 \\
\hline V/B alami & 0,3633 & ** & 0,2293 & ** & 0,0096 & $* *$ & 0,0094 & $* *$ & 0,0915 & $* *$ & 0,0057 \\
\hline A/B layang & 0,2071 & ** & 0,0489 & tn & 0,0342 & tn & 0,0534 & * & 0,0589 & tn & 0,0335 \\
\hline
\end{tabular}

Beberapa ratio panjang dan lebar daun serta ukuran sudut daun menunjukkan perbedaan sangat nyata antar stadia pertanaman, kecuali ratio $\mathrm{P} / \mathrm{TL}$ dan TL/TP, sudut apeks dan sudut vena alami, serta ratio sudut $\mathrm{A} / \mathrm{B}$ proyeksi layanglayang, yang diduga kurang dipengaruhi oleh lingkungan tumbuh tanaman. Faktor lingkungan yang mempengaruhi bentuk daun adalah cahaya, kelembaban dan temperatur. Tanaman yang tumbuh dengan intensitas cahaya matahari kuat biasanya memiliki daun tebal karena memiliki jaringan palisade tebal dan rapat demikian juga dengan jaringan bunga karangnya (Weier, Stocking, Barbour, \& Rost, 1982)

Hampir seluruh parameter (Rasio $\mathrm{P} / \mathrm{L}, \mathrm{P} / \mathrm{TL}, \mathrm{TL} / \mathrm{TP}, \mathrm{TL} / \mathrm{L}, \mathrm{HKr} / \mathrm{TL}$, apeks alami, vena alami, basis layang, apeks layang, V/A alami, dan A/B layang) menunjukkan perbedaan tidak nyata di antara helaian daun/klon. Hal ini memperkuat dugaan bahwa salah satu helaian daun dapat mewakili helaian daun lain. Oleh karena luas daun tengah lebih dominan maka daun tengah dapat dipergunakan untuk contoh dalam identifikasi klon karet melalui daun.

Akan tetapi analisis keragaman pada Tabel 2 memperlihatkan beberapa parameter seperti $\mathrm{HKr} / \mathrm{TP}$, sudut basal alami dan ratio $A / B$ alami serta ratio $V / B$ alami berbeda nyata di antara helaian dan dalam tangkai dan klon. HKr/TP yang nyata diantara helaian daun dalam klon menunjukkan bahwa proporsi perbedaan ukuran dari ketiga helaian daun di dalam satu tangkai cenderung disebabkan perbedaan panjang daun, bukan lebar daun. Perbedaan sudut basal alami dapat terjadi karena secara fisik helaian daun kanan dan kiri pada setiap tangkai lebih tertekan pertumbuhannya pada bagian basal akibat dominasi pertumbuhan helaian daun tengah, dimana sudut basal daun tengah cenderung lebih besar dibandingkan sudut basal kedua helaian daun di sisinya, terutama pada helaian daun yang saling berhimpitan di dalam satu tangkai. Akibat perbedaan sudut basal yang nyata tersebut, maka ratio sudut apeks dan sudut vena menjadi berbeda nyata di antara helaian daun dalam klon, meskipun secara sendirisendiri kedua sudut tersebut (apeks dan vena) tidak berbeda nyata diantara helaian daun dalam klon. Pada tanaman flavia, bentuk dan warna vena, warna, dan tekstur digabungkan untuk mengklasifikasikan daun. Jaringan syaraf tiruan yang disebut Jaringan Neural Probabilistik (PNN) digunakan sebagai pengklasifikasi (Kadir, Nugroho, Susanto, \& Santosa, 2011).

Hasil penelitian juga memperlihatkan seluruh parameter yang diamati berbeda nyata di antara tangkai dalam klon. Perbedaan tersebut dapat terjadi karena pemilihan contoh daun 
memiliki variasi ukuran daun dalam setiap klon yang cukup besar, dengan panjang daun dari 6,5 - 27,09 $\mathrm{cm}$ dan lebar daun maksimal dari 2,92-11,39 cm. Kecuali ratio $\mathrm{P} / \mathrm{TL}, \mathrm{TL} / \mathrm{TP}$, sudut vena alami, dan ratio A/B proyeksi layang-layang, seluruh parameter yang diamati (Tabel 1) memperlihatkan adanya interaksi antara klon dengan stadia pertanaman. Hasil ini mengindikasikan bahwa beberapa klon memperlihatkan terjadinya perubahan karakteristik daun pada setiap stadia pertumbuhan. Meskipun secara tunggal faktor klon berbeda nyata terhadap P/TL, TL/TP, sudut vena alami, dan ratio A/B proyeksi layang-layang, akan tetapi karena keempat parameter tersebut tidak dipengaruhi oleh lingkungan tumbuhnya (stadia pertumbuhan), maka tidak terlihat adanya pengaruh interaksi klon dan stadia pertanaman terhadap keempat parameter tersebut.

Adanya pengaruh dari interaksi klon dengan stadia pertumbuhan terhadap hampir seluruh karakter penciri yang diamati menunjukkan bahwa identifikasi klon melalui sifat daun tidak berlaku umum terhadap seluruh stadia pertumbuhan. Identifikasi klon harus dilakukan berdasarkan stadia pertumbuhan dengan mempergunakan klasifikasi karakter yang berbeda antara satu stadia dengan stadia pertumbuhan yang lain. Penelitian yang hampir sama juga dilakukan untuk mengidentifikasi gulma dengan melakukan pengenalan suatu spesies tumbuhan berdasarkan bentuk dan susunan tulangtulangnya dengan metode Moment Invariant (ciri bentuk dan citra daun gulma) dan Lacunarity (ciri tekstur dari citra gulma) (Herman \& Harjoko, 2015). Bruno, Plotze, Falvo, dan de Castro (2008), menyatakan bahwa analisis daun juga dapat dilakukan dengan menganalisis kompleksitas daun berdasarkan dimensi fraktalnya, dimana daun dianalisis dengan kompleksitas bentuk internal dan eksternal.

\subsection{Ratio Ukuran Panjang dan Lebar Daun Antar Klon dan Stadia Pertumbuhan}

Tabel 2 menunjukkan adanya pengaruh interaksi antara klon dengan stadia pertumbuhan terhadap karakteristik ratio panjang dan lebar daun $(\mathrm{P} / \mathrm{L}$, TL/L, $\mathrm{HKr} / \mathrm{TL}$, dan $\mathrm{HKr} / \mathrm{TP})$. Hasil ini membuktikan bahwa karakteristik yang berbeda nyata tersebut pada setiap klon berbeda pada setiap stadia pertumbuhan sebagaimana yang dikemukakan pada Gambar 1.

Pada klon IRR 42, IRR 118, dan PB 260 , ratio panjang dan lebar daun $(\mathrm{P} / \mathrm{L})$ daun pada kebun silang lebih kecil dari daun yang terdapat di kebun entres dan pembibitan polibeg, tetapi lebih besar dari daun pada areal TBM. Akan tetapi ratio P/L dari klon PB 330 yang paling kecil terdapat pada stadia kebun silang, menjadi lebih besar pada kebun entres, naik lebih besar pada bibit polibeg dan paling besar pada areal TBM. Nilai ratio P/L pada klon BPM 1 relatif sama besarnya pada daun yang terdapat di kebun silang dan bibit polibeg, dan kebun entres dengan areal TBM. Akan tetapi ratio P/L klon BPM 1 yang terdapat di kebun entres dan areal TBM lebih besar dari daun yang terdapat di kebun silang dan pembibitan.

Karakteristik ratio TL/L dari klon IRR 42 dan IRR 118 relatif sama, dimana ratio TL/L pada daun yang terdapat di kebun silang dan kebun entres relatif sama, tetapi lebih besar dari daun yang terdapat di areal TBM, namun lebih kecil dari daun yang terdapat di pembibitan polibeg. Ratio TL/L yang paling besar pada klon PB 330 terdapat di areal TBM dan yang paling kecil di kebun entres. Sedangkan pada klon BPM 1, ratio TL/L paling tinggi pada kebun entres dan areal TBM dan yang terendah pada kebun silang dan pembibitan polibeg.

Pada klon PB 330, ratio $\mathrm{HKr} / \mathrm{TL}$ yang paling besar terdapat pada daun contoh yang berasal dari kebun entres dan yang paling kecil pada daun yang berasal dari areal TBM. Akan tetapi pada klon IRR 118 dan PB 260, ratio HKr/TL yang paling besar pada daun yang berasal dari pembibitan polibeg dan yang paling besar berasal dari areal TBM. Fenomena yang hampir sama juga terlihat pada ratio $\mathrm{HKr} / \mathrm{TP}$ (Gambar 1).

\subsection{Karekteristik Sudut Daun Antar Klon dan Stadia Pertumbuhan}

Sebagaimana halnya terhadap panjang dan lebar daun, interaksi klon dan stadia pertumbuhan juga berpengaruh nyata terhadap ukuran sudut dan rationya. Hasil pengamatan yang disajikan pada 

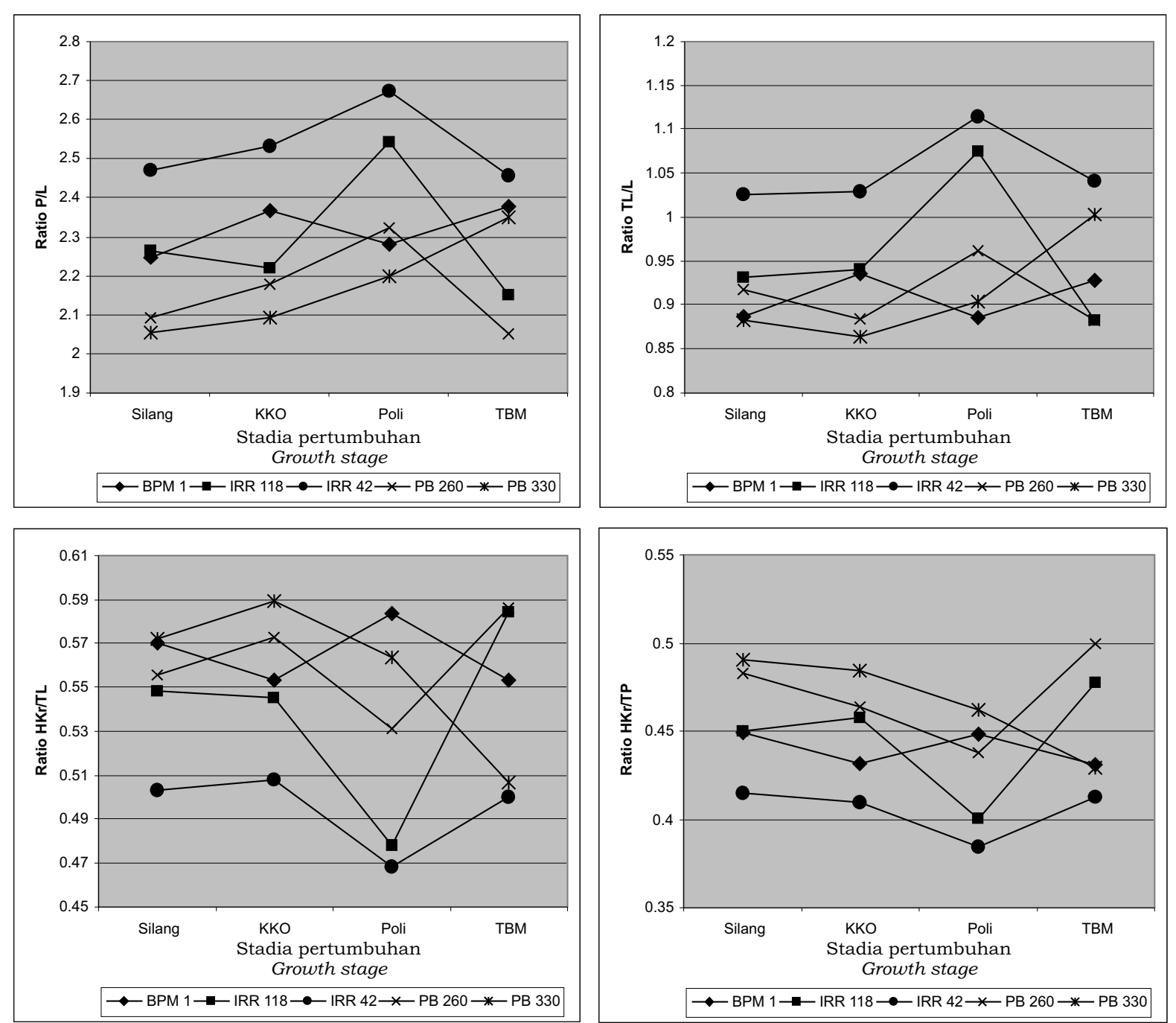

Keterangan (Remaks): Silang: kebun perslangan, KKO: kebun kayu okulasi, Poli: tanaman polibeg, TBM: tanaman belum menghasilkan

Gambar 1. Pengaruh interaksi klon dan stadia pertumbuhan terhadap beberapa ukuran ratio panjang dan lebar daun karet

Figure 1. Influence of clone and growth stage interaction of some length and wide rubber leaf ratio

Gambar 2 menunjukkan bahwa pada klon IRR 42, bentuk sudut apeks alami, sudut basal alami, maupun kedua sudut yang telah diproyeksikan memiliki pola yang sama, dimana besar sudut keempat karakter tersebut secara berturut-turut terkecil pada daun berasal dari pembibitan polibeg dan terbesar pada daun yang berasal dari areal TBM. Ukuran sudut pada daun yang berasal dari kebun silang lebih kecil dari TBM, namun lebih besar dari kebun entres dan pembibitan polibeg.
Sebaliknya pada klon PB 330, ukuran sudut daun paling besar terdapat pada kebun silang dan kebun entres, sedangkan yang paling kecil pada areal TBM. Pada klon PB 260, sudut yang lebih besar terdapat pada daun yang berasal dari kebun silang dan areal TBM, sedangkan yang paling kecil pada pembibitan polibeg.

Pola pengaruh interaksi klon dan stadia pertumbuhan juga terlihat jelas terhadap ratio sudut daun (Gambar 2). Pada 

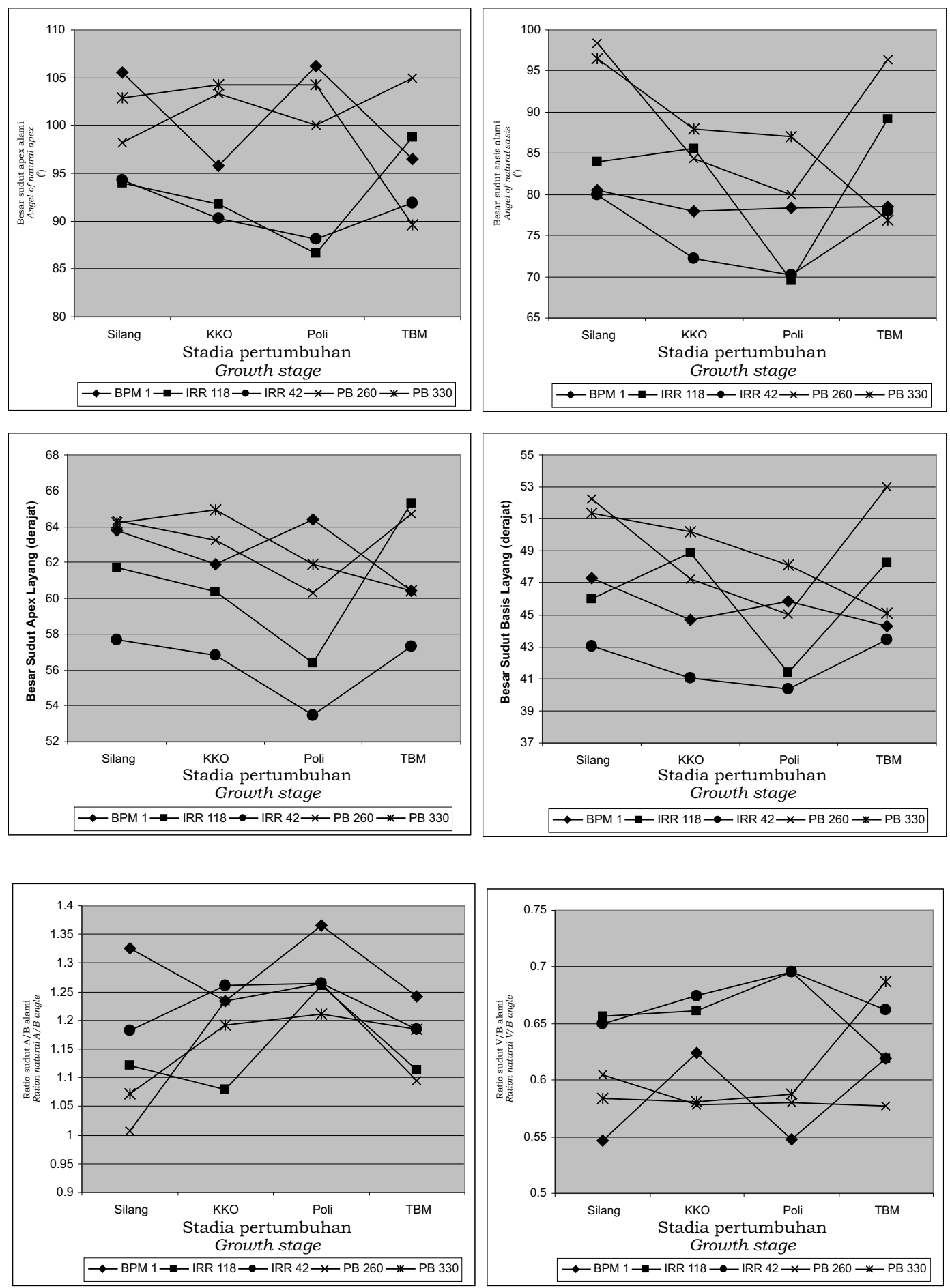

Keterangan (Remaks): Silang: kebun persilangan, KKO: kebun kayu okulasi, Poli: tanaman polibeg, TBM: tanaman belum menghasilkan

Gambar 2. Pengaruh interaksi klon dan stadia pertumbuhan terhadap ukuran sudut dan ratio antar sudut pada daun karet

Figure 2. Influence of clone and growth stage interaction of some length and wide ratio, and angle of rubber leaf 
klon IRR 42, ratio sudut paling besar terdapat pada daun yang berasal dari pembibitan polibeg dan kebun entres, sedangkan yang paling kecil pada daun berasal dari kebun silang dan areal TBM. Pada klon IRR 118, ratio antar sudut yang terbesar dijumpai pada daun yang berasal dari bibit polibeg, sedangkan yang lebih kecil pada daun yang berasal dari areal TBM atau kebun entres.

\section{Pengujian Teknik Digital dan Leafgram}

Pada penelitian sebelumnya, parameter penciri yang membedakan daun antar klon didasarkan pada pengukuran beberapa peubah alami yang terdapat pada daun seperti panjang dan lebar daun, letak titik pusat dan titik lipat, besar sudut daun pada posisi apeks dan basal, besar sudut vena, serta proyeksi besar sudut apeks dan sudut basal terhadap sisi daun pada lebar maksimum. Penelitian sebelumnya memanfaatkan komputer dengan Software Adobe Photoshop untuk melakukan pengukuran terhadap peubah-peubah tersebut, dengan tahapan scanning daun, cropping, dan pembacaan skala.

Teknik pengukuran secara digital tersebut membutuhkan fasilitas scanner, komputer, dan keterampilan tertentu dari operator. Persyaratan tersebut menimbulkan kesulitan jika fasilitas tersebut tidak tersedia, sehingga perlu dipertimbangkan alternatif teknik pengukuran lain yang dapat mengidentifikasi karakteristik daun dengan mudah, cepat, dan tentu saja dengan tingkat ketelitian yang tinggi. Untuk keperluan tersebut telah dirancang sebuah alat ukur sederhana yang dapat dipergunakan oleh siapapun jika telah dilatih terlebih dahulu. Alat tersebut terbuat dari kertas bergaris berskala ukur dan berskala sudut yang diberi nama "leafgram".

Dua teknik pengukuran yaitu secara digital dengan komputer dan manual dengan "leafgram" dilakukan terhadap peubahpeubah alami daun yang terdapat pada tujuh klon karet. Hasil analisis terhadap penggunaan kedua teknik pengukuran (Leafgram vs Digital) dan pengaruhnya terhadap klon dikemukakan pada Tabel 3.

Hal yang menarik dari Tabel 3 adalah bahwa peubah yang dipengaruhi oleh tangkai daun (sebagai ulangan) adalah peubah-peubah yang bersifat "ukuran alami" seperti panjang, lebar, letak titik lipat, titik pusat, dan lebar sisi helaian sebelah kiri daun. Sedangkan peubah yang bersifat "bentuk" yang dapat dikuantifikasi seperti besar sudut apeks, basal, vena, maupun proyeksinya tidak berbeda di antara tangkai daun. Hal ini menunjukkan bahwa bentuk daun yang diwakili sudut-sudutnya lebih stabil dibandingkan peubah-peubah kuantitatif lainnya.

Tabe1 3. Kuadrat tengah (KT) analisis keragaman antar metode pengukuran dan klon karet di kebun entres

Table 3. Mean square of analysis variation measurement method between rubber clone in budwoodgarden

\begin{tabular}{|c|c|c|c|c|c|c|c|c|}
\hline \multirow{3}{*}{$\begin{array}{c}\text { Peubah alami } \\
\text { Natural characters }\end{array}$} & \multicolumn{8}{|c|}{$\begin{array}{l}\text { Sumber keragaman (Source of square) } \\
\mathrm{db}=\text { derajat bebas (Freedom of degree }\end{array}$} \\
\hline & \multicolumn{2}{|c|}{$\begin{array}{l}\text { Ulangan } \\
\text { Replicate }\end{array}$} & \multicolumn{2}{|c|}{$\begin{array}{l}\text { Metode } \\
\text { Method }\end{array}$} & \multicolumn{2}{|c|}{$\begin{array}{c}\text { Klon } \\
\text { Clone }\end{array}$} & $\mathrm{M} \times \mathrm{K}$ & $\begin{array}{l}\text { Galat } \\
\text { Error }\end{array}$ \\
\hline & (14) & & (1) & & (6) & & (6) & $(182)$ \\
\hline Panjang daun & 26,469 & * & 0,118 & tn & 80,551 & * & 0,001 & 10,997 \\
\hline Lebar daun & 2,768 & * & 0,075 & tn & 18,237 & * & 0,000 & 1,168 \\
\hline Titik lipat daun & 5,268 & * & 9,316 & * & 13,146 & * & 0,185 & 1,860 \\
\hline Titik pusat daun & 6,617 & * & 0,029 & tn & 20,138 & * & 0,000 & 2,749 \\
\hline Lebar sisi kiri helaian & 0,652 & * & 0,846 & $\operatorname{tn}$ & 4,892 & * & 0,003 & 0,301 \\
\hline Sudut apeks & 66,030 & tn & 3,733 & tn & 517,146 & * & $\begin{array}{r}10,11 \\
4\end{array}$ & 50,166 \\
\hline Sudut basis & 55,741 & $\operatorname{tn}$ & 281,186 & * & 276,921 & * & 5,758 & 36,549 \\
\hline Sudut vena & 15,004 & tn & 6,519 & tn & 155,025 & * & 2,275 & 11,193 \\
\hline Sudut apeks layang & 24,903 & tn & 151,725 & * & 323,155 & * & 9,797 & 17,364 \\
\hline Sudut basis layang & 25,748 & tn & 166,519 & * & 210,563 & * & 4,200 & 10,724 \\
\hline
\end{tabular}

Keterangan (Remaks): *: berbeda nyata, tn: tidak nyata 
Sebagaimana penelitian sebelumnya (Suhendry \& Pasaribu, 2009) bahwa seluruh peubah penciri yang diamati pada penelitian ini dipengaruhi secara nyata oleh klon, sehingga identifikasi klon dapat dilakukan melalui peubah-peubah tersebut. Hasil penelitian pada Tabel 3 juga menunjukkan bahwa beberapa peubah berbeda nyata diantara metode (teknik) identifikasi yang dipergunakan. Perbedaan hasil pengukuran antara teknik digital dan manual dengan leafgram terjadi pada peubah titik lipat daun, sudut basal, dan kedua sudut hasil proyeksi layang-layang pada basal dan apeks. Teknik pengukuran tersebut tidak berbeda nyata pada peubah-peubah yang ukuran tetap secara alami seperti panjang daun, lebar daun maksimum, titik pusat daun, sudut apeks, dan sudut vena. Hal tersebut karena sebelum pengukuran peubah tersebut tidak ada perlakuan tertentu yang dilakukan terhadap daun.

Perbedaan titik lipat daun diduga akibat adanya perlakuan letak lipatan sebelum peubah diukur secara manual. Penetapan posisi daun terlebar secara digital dilakukan dengan memanfaatkan bantuan kotak batas tepi dan garis horizontal, sedangkan secara manual ditetapkan berdasarkan feeling (perkiraan) operator. Adakalanya ditemukan daun yang letak tepi daun terlebarnya tidak horizontal terhadap tulang daun yang telah diposisikan secara vertikal. Pada daun yang demikian, titik lipat pada komputer ditentukan dengan bantuan garis horizontal pada bagian tengah antara letak titik daun terlebar pada sisi kiri helaian dengan letak titik daun terlebar di sisi kanan. Akan tetapi pada penetapan secara manual, lipatan daun ditentukan dengan berpedoman pada titik daun paling lebar di kedua sisi helaiannya, meskipun kadangkadang tidak memotong secara horizontal garis tegak tulang daun (Gambar 3).

Letak titik tepi daun terlebar tidak memotong tegak lurus garis tulang daun, maka dalam implementasinya pengamatan TL daun perlu ditetapkan letak titik daun terlebar pada sisi kiri helaian menjadi patokan pelipatan daun terhadap kesejajaran posisi tulang daun.

Akibat dari perbedaan cara penetapan titik lipat pada kedua teknik identifikasi tersebut, maka letak titik daun terlebar di kedua sisi juga berbeda. Kedua titik tepi daun terlebar tersebut dipergunakan sebagai pedoman membentuk sudut layang-layang baik terhadap sudut apeks maupun basal. Dalam pengujian ini, perbedaan menentukan letak titik tepi daun terlebar menyebabkan hasil proyeksinya terhadap sudut apeks dan basal juga berbeda nyata (Tabel 2).

Sudut basal yang berbeda nyata di antara teknik identifikasi disebabkan karena ukurannya yang relatif kecil,

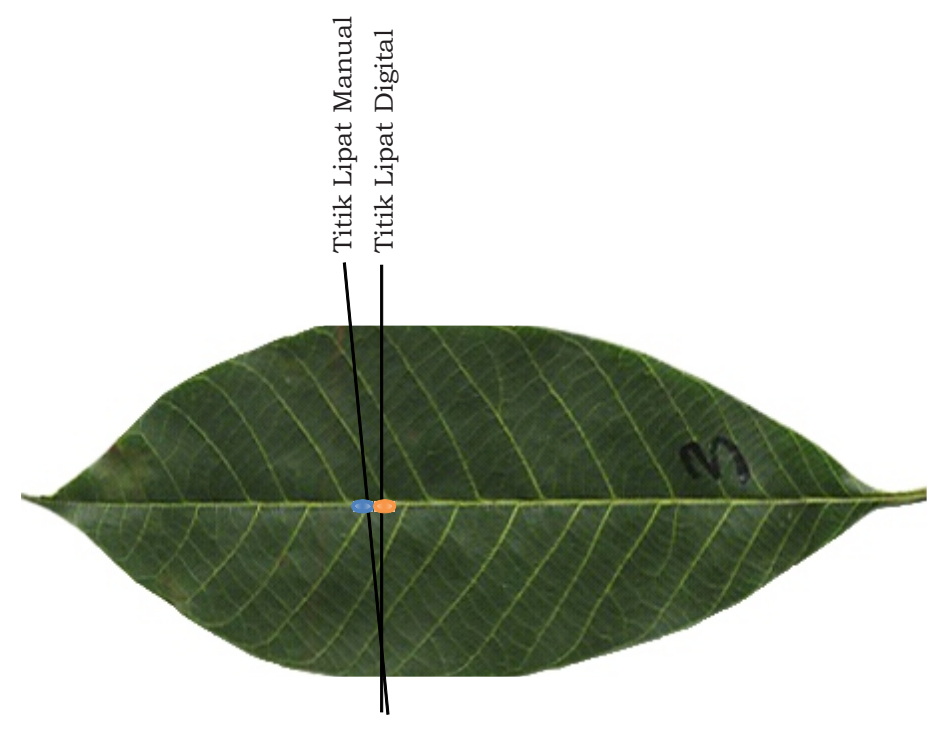

Gambar 3. Perbedaan penetapan posisi titik lipat berdasarkan letak daun terlebar pada kedua sisi daun

Figure 3. Stipulating difference of position fold point based on wider leaf at both sides 
sehingga membutuhkan tingkat ketelitian yang lebih tinggi pada saat sudut tersebut diukur secara manual. Oleh karena itu diperlukan pelatihan dan pengulangan cara mengukur yang lebih sering pada operator. Pengaruh tingkat ketelitian operator tersebut tidak menyebabkan fenomena antar klon berbeda. Hal tersebut terbukti dari tidak nyatanya interaksi metode dengan klon. Tidak nyatanya interaksi teknik identifikasi dengan klon menunjukkan bahwa teknik pengukuran karakteristik daun karet tidak dipengaruhi oleh klon, artinya klon apapun dapat diukur dengan salah satu teknik identifikasi (digital atau manual).

Pada peubah yang dipengaruhi oleh metode identifikasi seperti titik lipat daun, sudut basal, proyeksi layang sudut apeks dan basal (Gambar 4) terlihat pola yang
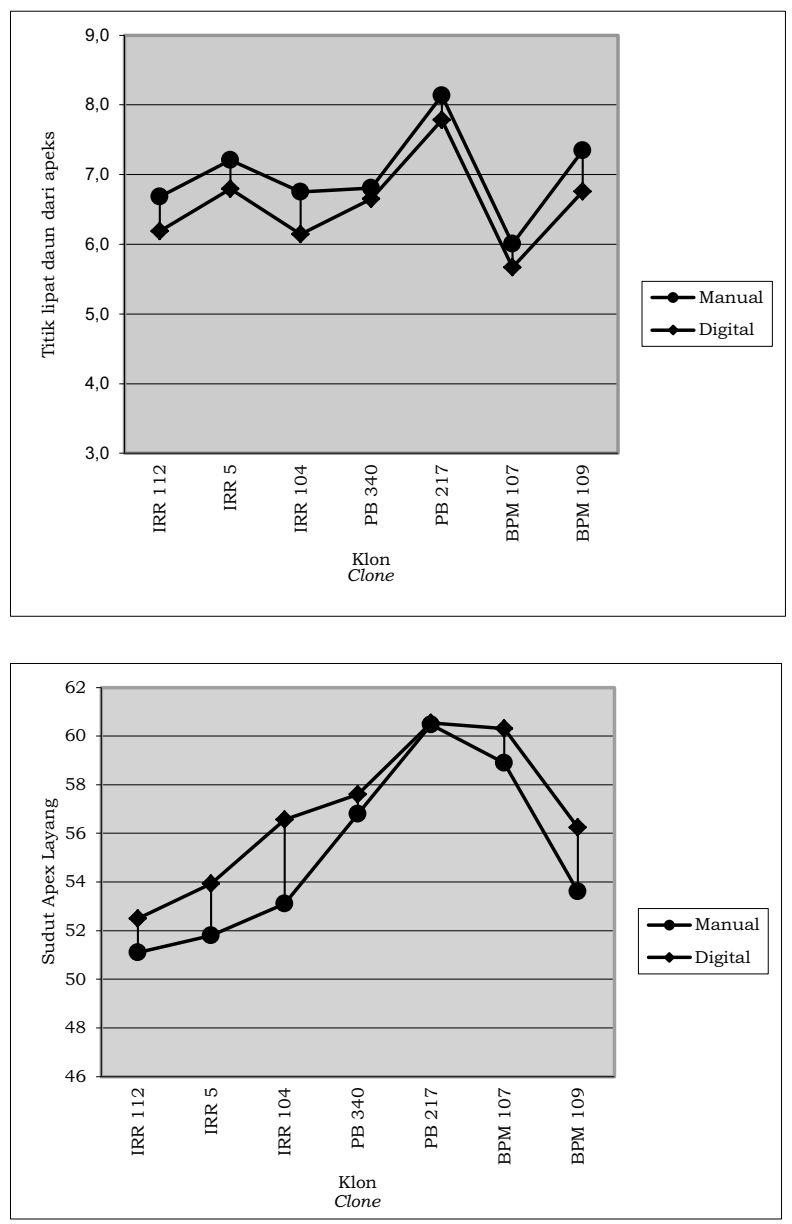

sama hasil pengukuran pada setiap klon. Klon yang memiliki nilai titik lipat paling besar seperti PB 217 dibanding klon lain yang diukur dengan teknik manual, tetap sebagai klon dengan titik lipat terbesar dengan pengukuran secara digital. Demikian juga pada klon BPM 107, dimana klon tersebut memiliki titik lipat paling kecil dibandingkan klon lain, baik secara manual maupun digital.

Secara umum pengukuran secara manual menghasilkan nilai yang lebih besar dibandingkan pengukuran secara digital. Fenomena yang sama terjadi pada peubah penciri sudut basal daun, proyeksi sudut layang basal. Sedangkan pada proyeksi sudut layang apeks hasil pengukuran dengan teknik digital lebih besar dari manual pada setiap klon. Lebih besarnya hasil pengukuran TL, sudut basal alami dan
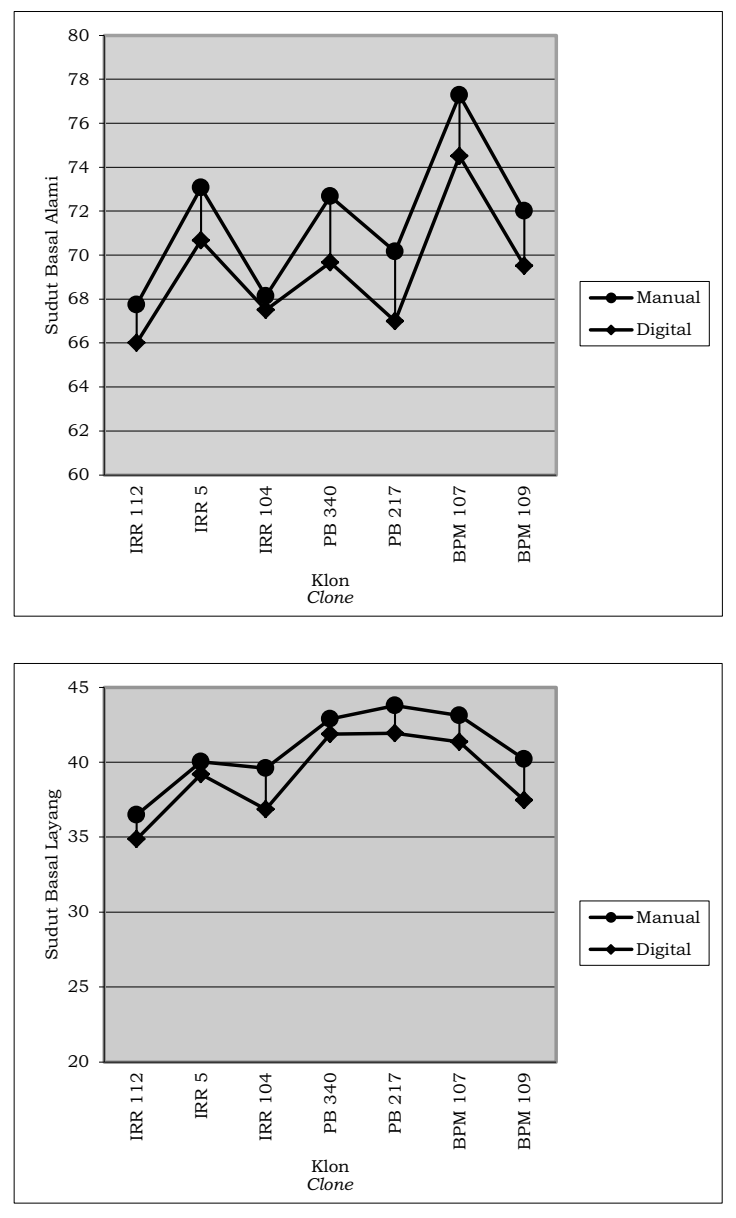

Gambar 4. Pola hasil pengukuran beberapa karakteristik daun melalui teknik digital dan manual pada setiap klon contoh

Figure 4. Measurement pattern some of leaf characteristics through digital and manual techniques every sample clone 
sudut basal layang disebabkan pengaruh teknik cropping daun pada teknik digital. Pada teknik digital, sebelum daun diukur terlebih dahulu dilakukan pemisahan latar belakangnya (background) melalui teknik cropping. Teknik cropping dilakukan secara visual dengan memanfaatkan magictool pada program Software Adobe Photoshop. Teknik ini menyebabkan irisan tepi daun lebih masuk ke arah dalam sehingga ukuran daun menjadi lebih kecil yang berakibat letak lebar daun maksimum bergeser ke arah apeks. Hal ini menyebabkan jarak titik lipat daun dari apeks lebih kecil bila dibandingkan jarak titik lipat daun yang tidak dicrop dan diukur secara manual. Akibat semakin tingginya letak titik lipat tersebut menyebabkan proyeksi sudut basal langsung menjadi lebih kecil dan sudut apeks layang menjadi lebih besar pada pengukuran secara digital dibandingkan secara manual. Ukuran yang mengecil akibat cropping tersebut pada teknik digital juga menyebabkan sudut basal alami bertambah kecil dibandingkan dengan yang tidak dicrop (diukur manual). Ini menjadi salah satu kelemahan pada teknik digital bila operator pelaksananya kurang ahli dan teliti.

Penelitian yang lebih canggih telah dilakukan untuk mengidentifikasi biji gulma dengan menggunakan kamera yang memiliki sensor dengan kualitas gambar yang bagus sehingga hasil pencitraanya dapat digunakan untuk mengidentifikasi jenis gulma. Namun dari hasil penelitian tersebut ada beberapa hal penting yang menjadi catatan diantaranya harus dikumpulkan database gambar yang diambil secara menyeluruh dan jangan ada tumpang tindih hasil gambar yang diperoleh (Weis \& Gerhard, 2007). Kumar et al (2012), juga menyampaikan bahwa telah dilakukan identifikasi spesies tanaman menggunakan pengenalan visual secara otomatis (leafsnap) dari foto daun suatu tanaman.

\section{Konsistensi Ukuran Daun di Kebun Entres yang Berbeda}

Hasil penelitian konsistensi ukuran daun di tiga daerah yang berbeda menunjukkan tidak berbeda nyata untuk semua karakter yang diamati dari klon PB 260. Nilai kuadrat tengah (KT) terhadap analisis konsistensi ukuran daun pada tiga daerah yang berbeda dapat dilihat pada Tabel 4.

Hasil analisis menunjukkan bahwa dari sepuluh karakter pembeda yang dinilai menunjukkan hal yang sama setelah dianalisis. Ini menunjukkan bahwa karakter klon yang sama tidak akan berbeda antara tempat yang satu dengan tempat lainnya. Pada identifikasi gulma umur 45 hari juga disebutkan bahwa lokasi tumbuhnya tanaman tidak mempengaruhi fitur bentuk secara umum dengan analisis gambar biner (Woebbecke, Meyer, Bargen, \& Mortensen, 1995).

Tabel 4. Kuadrat tengah (KT) analisis keragaman konsistensi ukuran daun pada tiga daerah yang berbeda

Table 4. Mean square of analysis variation ofleaf size consistency at three different areas

\begin{tabular}{|c|c|c|c|c|c|}
\hline \multirow{2}{*}{$\begin{array}{c}\text { Peubah alami } \\
\text { Natural characters }\end{array}$} & \multicolumn{5}{|c|}{$\begin{array}{l}\text { Sumber keragaman (Source of square) } \\
\mathrm{db}=\text { derajat bebas (Freedom of degree) }\end{array}$} \\
\hline & \multicolumn{2}{|c|}{$\begin{array}{l}\text { Ulangan } \\
\text { Replicate }\end{array}$} & \multicolumn{2}{|c|}{$\begin{array}{l}\text { Daerah } \\
\text { State }\end{array}$} & \multirow{2}{*}{$\begin{array}{l}\text { Galat } \\
\text { Error } \\
437,65\end{array}$} \\
\hline Panjang daun & 450,60 & $\operatorname{tn}$ & 528,31 & $\operatorname{tn}$ & \\
\hline Lebar daun & 76,22 & tn & 82,06 & $\operatorname{tn}$ & 75,25 \\
\hline Titik lipat daun & 130,24 & tn & 289,62 & $\operatorname{tn}$ & 103,68 \\
\hline Titik pusat daun & 131,47 & $\operatorname{tn}$ & 131,83 & tn & 131,41 \\
\hline Lebar sisi kiri helaian & 18,89 & $\operatorname{tn}$ & 19,67 & $\operatorname{tn}$ & 18,76 \\
\hline Sudut apeks & 15452,5 & tn & 16771,4 & tn & 15232 \\
\hline Sudut basis & 9539,7 & tn & 9767,7 & tn & 9501,7 \\
\hline Sudut vena & 4812,6 & tn & 5141,3 & $\operatorname{tn}$ & 4757,8 \\
\hline Sudut apeks layang & 6200,2 & tn & 6961,3 & $\operatorname{tn}$ & 6073,1 \\
\hline Sudut basis layang & 3897,3 & tn & 4407,4 & $\operatorname{tn}$ & 3812,3 \\
\hline
\end{tabular}




\section{KESIMPULAN}

Dari hasil penelitian yang telah dilakukan, dapat ditarik kesimpulan sebagai berikut perbedaan nyata antara karakteristik beberapa klon pada pengujian ini telah memperkuat hasil sebelumnya, yang menunjukkan bahwa karakteristik daun dapat dipergunakan untuk mengidentifikasi klon karet. Sebagian besar parameter penciri daun ternyata dipengaruhi oleh kondisi lingkungan tumbuhnya akibat pengaruh cahaya, kelembaban dan temperatur, tetapi beberapa penciri lainnya (P/TL, TL/TP, sudut apeks alami, sudut vena alami dan proyeksi sudut A/B) tidak nyata dipengaruhi lingkungan tumbuh. Interaksi klon dan lingkungan tumbuh berbeda sehingga identifikasi klon melalui karakteristik daun harus dilakukan berdasarkan stadia pertumbuhan. Tempat tumbuh yang berbeda akan menghasilkan karakter yang sama Hasil pengujian teknik identifikasi menunjukkan bahwa seluruh parameter penciri daun yang bersifat alami berbeda diantara klon, tetapi sebagian besar penciri tidak berbeda diantara metode yang diuji, kecuali titik lipat, sudut basal dan proyeksi sudut. Tidak ada pengaruh interaksi klon dan teknik identifikasi sehingga kedua teknik dapat dipergunakan untuk mengidentifikasi seluruh klon.

Selanjutnya untuk pelaksanaan kegiatan penelitian berikutnya disarankan untuk menghilangkan pengaruh hasil pengukuran diantara metode digital dan manual, diperlukan pelatihan kepada operator agar memiliki tingkat ketelitian lebih tinggi. Penggunaan teknik manual dengan leafgram lebih sederhana dibandingkan teknik digital, oleh karena itu pembuatan database karakter penciri sebaiknya dilakukan dengan teknik leafgram.

\section{DAFTAR PUSTAKA}

Bruno, O.M., Plotze, R.d.O., Falvo, M., \& de Castro, M. (2008). Fractal dimension applied to plant identification. Information Science, 178(12), 27222733. Doi : 10.1016/j.ins.2008.01. 023.
Cerutti, G., Tougne, L., Mille, J., Vacavant, A., \& Coquin, D. (2 $\left.\begin{array}{llll}2 & 0 & 1 & 3\end{array}\right)$. Understanding leaves in natural images-a model-based approach for tree species identification. Computer Vision and Image Understanding, $117(10), \quad 1482-1501$. Doi : 10.1016/j.cviu. 2013.07.003.

Herman., \& Harjoko, A. (2015). Pengenalan spesies gulma berdasarkan bentuk dan tekstur daun menggunakan jaringan syaraf tiruan. Indonesian Journal of Computing and Cybernetics Systems, 9(2), 207-218. Doi : 10.22146/ijccs.7549.

Hearn, D.J. (2009). Shape analysis for the automated identification of plants from images of leaves. Taxon, 58(3), 934954.

Kadir, A., Nugroho, L.E., Susanto, A., \& Santosa, P.I. (2011). Leaf classification using shape, color, and texture features. International Journal of Computer Trends and Technology, 2011, 225-230.

Keppel, G., \& Wickens, T.D. (1973). Design and Analysis. A Researcher's Handbook. New Jersey, USA: Prentice Hall, Inc.

Kumar, N., Belhumeur, P.N., Biswas, A., Jacobs, D.W., Kress, W.J., \& Lopez, I.C. (2012). Leafsnap: A computer vision system for automatic plant spesies identification. Computer Vision-ECCV 2012, 7573, 502-516.

Laga, H., Kurtek, S., Srivastava, A., \& Miklavcic, S.J. (2014). Landmark-free statistical analysis of shape of plant leaves. Journal of Theoretical Biology, $363,41-52$. D o i : 10.1016/j.jtbi.2014.07.036.

Suhendry, I., \& Pasaribu, S.A. (2009). Identifikasi klon karet melalui karakteristik daun. 1. Variasi ukuran daun. Jurnal Penelitian Karet, 27(1), 120.

Volkenburgh, E.V. (1999). Leaf expansion-an integrating plant behavior. Plant, Cell \& Environment, 22(12), 1463-1473. Doi : 10.1046/j.1365-3040.1999.00514.x. 
Weier, T.E., Stocking, C.R., Barbour, M.G., \& Rost, T.L. (1982). Botany an introduction to plant biology. California, USA : John Wiley \& Sons.

Weis, M., \& Gerhards, R. (2007). Identification of Weeds from Digital Images. Agricultural Field Trials, 2, $7 \mathrm{p}$.
Woebbecke, D.M., Meyer, G.E., Bargen, K.V., \& Mortensen, D.A. (1995). Shape features for identifying young weeds using image analysis. Transactions of the ASAE, 38(1), 271-281. Doi : $10.13031 / 2013.27839$.

Zhao, C., Chan, S.S.F., Cham, W.K., \& Chu, L.M. (2015). Plant identification using leaf shape-A pattern counting approach. Pattern Recognition, 48(10), 3203-3215. Doi : $10.1016 /$ j.patcog.2015.04.004. 